\title{
AUDITOR WORKLOAD AND ITS IMPLICATION ON AUDITOR'S PROFESSIONAL ABILITY
}

\author{
Ely Suhayati \\ Department of Accounting, Universitas Komputer Indonesia, Bandung, Indonesia
}

\begin{abstract}
The purpose of this study was to determine how much auditors' workload can lead to dysfunctional auditors and how much dysfunctional auditors have implications on professional auditors' ability. The method in this research is descriptive verification with the Structural Equation Modeling test as a tool in making conclusions. The sample in this study were 97 public accounting firms on Java island, with senior and junior public accountant observation units. The results of this study indicate that auditors' workload accumulation will cause stress on auditors so that it triggers dysfunctionality and has an impact on decreasing auditors' professional ability. In conclusion, the more the auditor's workload, the more positive the auditor's attitude. Besides, the lower the auditor's dysfunctionality, the better the auditor's professional skill. It indicates that an auditor will be able to tackle obstacles in the direction of advanced Indonesia.
\end{abstract}

Keywords: Auditor Workload, Auditor Dysfunctionality, Auditor Professional Ability

DOI: http://dx.doi.org/10.15549/jeecar.v9i1.869

\section{INTRODUCTION}

External auditors have a public trust and clients to prove financial statements presented fairness by the company's internal parties. External auditors must audit financial statements that have been made because financial statements do not rule out possible errors, both intentional and unintentional. Financial statements towards external auditors' confidence require auditors to pay attention to their professional abilities (Manalu, 2016). A professional auditor considers material importance, or not, with accurate information because this relates to opinion types to be published. Even more, the auditor knows his professional responsibilities, and more auditing skills will be guaranteed and avoiding auditor dysfunction (Dahlia \& Octavianty, 201617).
Currently, many people question external auditors considering professionalism that many external auditors are involved in scandals due to excessive workloads. That can lead to dysfunctional behavior because external auditors must be able to act professionally as individuals capable of presenting financial information that will be used as material for executive decisionmaking (Syarif \& Fitriyani, 2017).

An auditor receives the workload in carrying out his work program for a specific time period, workload needs to be considered by an auditor to assess his performance quality because high workloads can cause fatigue and auditor dysfunctional emergence behavior so can reduce an auditor's ability to find errors or report irregularities (Hussin et al., 2018). Too high a 
workload received from overtime work system both on working days and on rest days and official holidays results in an auditor having a weak mental and physical condition. Overall, it makes an auditor's performance even lower (Longo \& Leva, 2019). Conceptually, the workload provided by an auditor can be viewed as a difference in energy available at each work received with the dynamism required to work on a program effectively and efficiently (Liu, 2016).

Auditors who have excessive workloads above their abilities and cause fatigue will result in dysfunctional behavior. They will reduce the ability to find symptoms of fraud which will result in low audit quality (Syarif \& Fitriyani, 2017). Quantitative workload pressure is one of the potential dysfunctional results, such as weakening audit quality and reducing his professional ability to carry out his work program to affect decision-making consideration material by clients (Chen et al., 2020). Auditors who tend to behave dysfunctionally due to the small amount of time or less time managing the audit program can make audit results premature. Such statements and evidence presented by a client are not appropriate in investigating a problem. Relevant, insufficient relevant evidence obtained less accurate and precise audit process and audit stage errors (Al Shbail et al., 2018). Donnelly et al. (2003) states that a case study in America of dysfunctional auditors is directly related to the professional ability of auditors, in line with McNamara (2008), which says that "dysfunctional has serious implications for audit quality." However, the research above does not discuss dealing with the auditor is dysfunctional. Based on the description of the background and phenomena above, this research is important because dysfunctional must be addressed positively so that it can improve the professional ability of auditors so that it has an impact on increasing the economic capability of the Indonesian nation.

Therefore, the purpose of this study was to determine how much auditors workload can lead to dysfunctional auditors and how much dysfunctional auditors have implications on professional auditors' ability. The novelties of this study require auditors who have professional abilities so that they can support superior human resources creation towards advanced Indonesia and bring the Indonesian economy towards new achievements. In addition, the workload needs to be managed so as not to cause stress for the auditor.

\section{LITERATURE REVIEW}

According to Irzal (2016) states that an Auditor Workload or Auditor Workload is an ability portion that must be issued by an auditor to meet work "demand" with a certain time. According to Saleh (2018) which states that an Auditor's Workload is a subjective and individual response by workload received, situation auditor and personal factors (stress, skills, or experience), or contextual factors (time pressure, noise, disruption, or organizational change problems). Besides, Putro \& Sari (2018) stated that Auditor's Workload is the number of physical and mental activities an auditor carries out and completes his work within a specific time. Based on the experts' statements, it can be concluded that Auditor's Workload is several physical and mental activities that must be completed within a particular time. Auditor's ability requires a portion implementation and can burden the auditor.

According to Supriyono (2018), an Auditor's Dysfunctionality is a behavior auditor in carrying out an audit program that can reduce audit directly quality or indirectly, which will cause loss or not an entity objectives achievement. Unaradjan (2019) states that a Dysfunctional Auditor is an attitude contrary to organization goals that will cause harm to an organization. In addition, Puspita (2018) states that a Dysfunctional Auditor is a conflict whose existence can harm the organization and prevent an organization from achieving its goals. Based on the experts' statements, it can be concluded that Auditor Dysfunctionality is auditor behavior that is contrary to organization goals, and its existence can harm the organization.

Human behavior related to psychological, sociological, and social psychological factors can be both functional behavior and dysfunctional behavior. There is no limit to individuals' functional behavior or dysfunctional behavior, and it depends on the individual who does it.

According to Edy (2016), the definition of functional and dysfunctional behavior are several types of behavior that support organizational goals and improve performance are functional or constructive forms of behavior. These behaviors benefit or support the main organization's goals in serving corporate interests. On the other hand, there are types of behavior that hinder 
organizational performance, namely, dysfunctional behavior or descriptive. Behavior is undesirable, and interested parties must make efforts so that the behavior does not threaten corporate interests. Functional forms of behavior are usually referred to in management circles as constructive or cooperative behavior forms, while dysfunctional behavior forms are also called descriptive or non-cooperative. Both can be grouped by function and handling action.

Dysfunctional characteristics focus more on premature sign-off and underreporting of chargeable time because this behavior is very prone to occur and is strongly related to time budget pressure (Sunaryo, 2018). As for a Dysfunctional External Auditor, according to Sunaryo (2018), for this research, which endangers auditors professional ability to have two dimensions are as follows:

\section{Underreporting of time}

Underreporting of time or underreporting of chargeable time is dysfunctional behavior carried out by external auditors by not reporting an actual time or using their personal time in carrying out audit procedures with a motivation to avoid or minimize excessive planning. External auditors often call this behavior eating time practice. Underreporting can be done by arriving a few hours early, continuing to work at lunch, or bringing work home on weekends without writing these extra hours on the timesheet. In conclusion, underreporting of time shows a dedication or commitment from external auditors to the company or its clients. From the discussion above, three indicators for this study are as follows:

a. Work carried out at home

b. Failure to report an actual time it took to complete audit procedures

c. Work at lunch or arrive a few hours early

\section{Premature sign off}

Premature sign-off is external auditors' behavior to terminate audit procedure steps because a workload has implications for the professional ability of auditors. From the discussion above, the three indicators for this study are as follows:

a. Not following all audit procedures in accordance with SPAP or existing regulations

b.Doing over time

\section{c. Easily accept reasons and evidence from clients}

Arens et al., (2017) state that Auditor Professional Capability is a responsibility borne by an auditor and is more than just fulfilling society laws and regulations. Moreover, Heri (2017) states that an Auditor's Professional Ability is behavior, goals, and qualities that shape a character or characterize a professional, including auditors who have knowledge and abilities from various disciplines in compiling rules or codes conduct that defines ethical (professional) behavior for members that profession. In addition, according to Perwita et al. (2019), the Auditor's Professional Ability is a special application of ethical principles that emphasize various guidelines for knowledge, awareness, respect for divine law, responsibility acceptance from assignments. Knowing ethical norms behavior recognized by society is applicable to all types of professions, especially an auditor. Based on the experts' statements, it can be concluded that Auditor Professional Ability is auditor behavior in each auditor various disciplines abilities assignment responsibility accepting and ethical norms knowledge behavior that is recognized by society.

Factors underlying an auditor's dysfunctional behavior, according to Anggraini \& Nafasati (2018), an auditor is believed to be a company's financial statements independently party who can provide an assessment. An auditor must be as professional as possible in doing his job by avoiding errors in an assessment caused by heavy workloads that can trigger dysfunctional Auditors. And according to Pesireron (2018), a professional auditor will produce quality work because professionalism means that an auditor has used his ability to minimize audit workload. Also, an auditor is applying high ethics in carrying out his work and being able to face challenges and dedicate himself to a professional commitment formed voluntarily in a person to avoid dysfunctional behavior.

An auditor's dysfunctional behavior may cause a decrease in an auditor's professional ability. According to Suhayati (2012), an auditor is in a low condition or is experiencing work stress due to a complex workload that can lead to dysfunctional audit behavior, affecting his professional audit skills. According to Putri et al. (2019), an auditor's dysfunctional behavior is harmful to a professional and a client, but 
auditors who have an ability to professionalism will have a good understanding of how to behave. Such as training or changes in a reward system can reduce that dysfunctional behavior to a minimum. And according to Jaya (2018), an increase in workload in quality and quantity can result in a significant decrease in audit quality, and the auditor can release this pressure through dysfunctional behavior.

\section{METHODOLOGY}

The author uses a descriptive verification method (Causal). Descriptive research is research that provides an overview of variables characteristics under study in a situation. Meanwhile, Verification (Causal) is a study that aims to determine the causal relationship between variables through hypothesis testing, test tool used in this study is Structural Equation Modeling as a tool in making conclusions, while data collection techniques through questionnaires using structured questions list aimed at respondents.

Research in hypothesis testing form aims to examine a relationship between variables that have been stated in the research hypothesis. In order for hypothesis testing that will begin with data collection to be clearer and more focused, these variables must be operationalized. The main purpose of operationalizing or defining operationally is to measure a variable so that researchers can collect data and then carry out statistical analysis. This study consisted of three variables, namely an Auditor Workload (X) according to Vanchapo (2020), is a group or a number of activities that must be completed by an organizational unit or an officeholder within a certain time, with indicators, namely audit activities number and time for audit completing. Then, a Dysfunctional Auditor (Y), according to Supriyono (2018), is auditors' deviant behavior in carrying out audit activities that can reduce audit quality directly or indirectly, with indicators namely underreporting of time and premature sign-off. Besides, the Professional Ability of the Auditor (Z), according to Hery (2017), is auditors professional proficiency level in conducting audits carried out with professional skills and accuracy on control structures implementation, with indicators namely adherence to ethics professional code, knowledge, skills, confidence in profession and relationships with fellow professions. These variables are measured using a

\section{Likert's Summated Rating.}

Accountant firm located in Java Island based on directory Institute Akuntan Publik Indonesia there are 502 public accounting firms including branches, while a sample is taken using a Slovin formula (Mufarrikoh, 2019), these equations are described in the model 1:

$$
n=\frac{N}{1+N .(e)^{2}}
$$

The information in equation 1 above shows a minimum sample size for a Public Accounting Firm in Java, $\mathrm{n}$ shows sample size, $\mathrm{N}$ shows a whole sample or population, and e indicates error degree $10 \%$ or 0,1 .

So based on the above calculation, the minimum number of Public Accounting Firms, as a sample in this study, is 83 . That allows results to be more optimal,

Researchers added 14 samples. That totals 97 Public Accounting Firms. Three junior auditors represent each public accounting firm. The analysis unit or observation unit in this study is a junior auditor because it is indicated that there are many audit workload pressures.

Because researching more than one public accounting firm, this research uses a data collection method in a survey method, while data type in this study consists of primary and secondary data. Primary data was carried out using questionnaires and interviews. A written questions questionnaire is a set that has been prepared in advance and submitted to respondents to answer in writing as well. From distributing questionnaires results and collecting secondary data, data processing was carried out in 4 stages: editing, entry, tabulation, and data analysis. Given that a model in this study is a model of causality (causal relationship), then to test a proposed hypothesis, Structural Equation Modeling analysis is used.

\section{RESULTS}

Figure 1 shows $t_{\text {statistical }}$ amount value on the Auditor Workload (X), Auditor Dysfunctionality $(Y)$, and Auditor Professional Ability (Z).

Table 1 shows a direction, and estimated variables value the Auditor Workload (X), Auditor Dysfunctionality (Y), and Auditor Professional Ability (Z) 


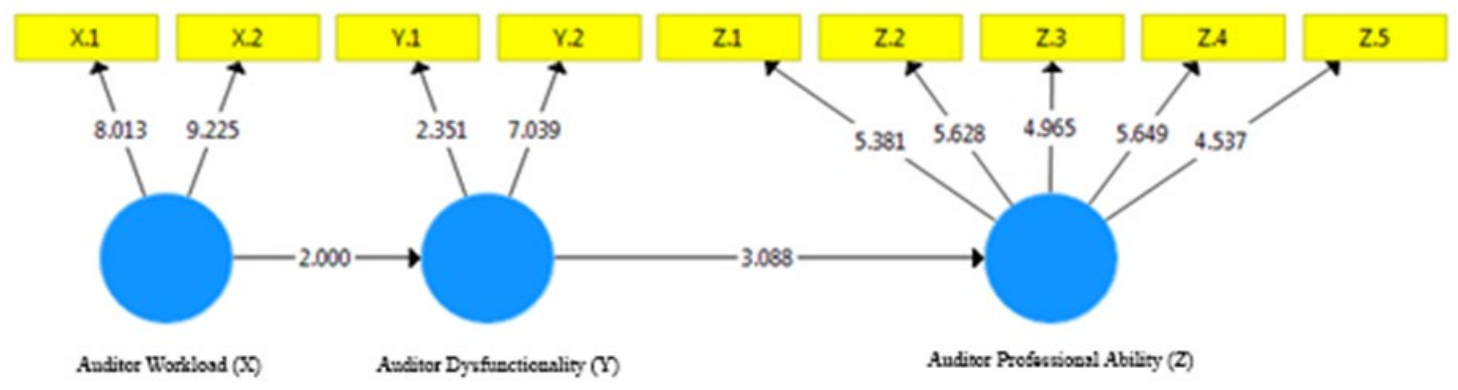

Figure 1: Path Coefficient Value

Table 1: t-Test Value

\begin{tabular}{|c|c|c|c|c|c|}
\hline Variable Leave & $\begin{array}{c}\text { Path } \\
\text { Coefficient }\end{array}$ & $\mathrm{t}_{\text {statistical }}$ & $\mathrm{t}_{\text {critical }}$ & Information & $\begin{array}{c}\text { Variable } \\
\text { Leave }\end{array}$ \\
\hline $\begin{array}{c}\text { Auditor Workload }(\mathrm{X}) \rightarrow \text { Auditor } \\
\text { Dysfunctionality }(\mathrm{Y})\end{array}$ & 0,211 & 2,000 & 1,661 & $\mathrm{H}_{\mathrm{o}}$ rejected & Significant \\
\hline $\begin{array}{c}\text { Auditor Dysfunctionality }(\mathrm{Y}) \rightarrow \\
\text { Auditor Professional Ability }(\mathrm{Z})\end{array}$ & $-0,248$ & 3,088 & 1,661 & $\mathrm{H}_{\mathrm{o}}$ rejected & Significant \\
\hline
\end{tabular}

Notes: Error Degree $10 \%$ or 0,1

Source: SmartPLS Software Statistical Results 3, 2020

Based on the results t-test in an output Table 1 and a Path Coefficient Value in Figure 1 above, it can be seen that the t-statistical value Auditor Workload to Auditor Dysfunctionality is 2,000 and Auditor Dysfunctionality to Auditor Professional Ability is 3,088. Also, two variables are more significant than 1,661. Because tstatistical value is greater than tcritical value, with an error rate of $10 \%$ or 0,1 , it is decided that $\mathrm{H} 0$ is rejected and $\mathrm{Ha}$ is accepted with a sample estimate value an Auditor Workload to Auditor Dysfunctionality is 0,211 dan Auditor Dysfunctionality to Auditor Professional Ability is $-0,248$. Based on test results with a confidence level of $90 \%$ or 0,9 , it can be concluded that an Auditor Workload has a positive effect on a Dysfunctional Auditor in Public Accounting Firms in Java. It means that any increase in Auditor Workload will be followed by Auditor Dysfunctional appearance behavior. Meanwhile, a Dysfunctional Auditor has a negative effect on Auditors Professional Ability in Public Accounting Firms in Java, which means that a decline in Dysfunctional Auditor behavior will increase Auditors Professional Ability.

Table 2 shows contributions percentage from variables the Auditor Workload (X), Auditor Dysfunctionality (Y), and Auditor Professional Ability (Z)

Table 2: Determination Analysis Coefficient (R2

\begin{tabular}{|l|l|l|l|}
\hline & $\begin{array}{l}\text { Structural } \\
\text { Path } \\
\text { Coefficients }\end{array}$ & $\begin{array}{l}\text { Correlation } \\
\text { With Bound } \\
\text { Variables }\end{array}$ & $\begin{array}{l}\text { Influence } \\
(\%)\end{array}$ \\
\hline $\begin{array}{l}\text { Auditor Workload }(\mathrm{X}) \rightarrow \text { Auditor } \\
\text { Dysfunctionality }(\mathrm{Y})\end{array}$ & 0,211 & 0,869 & 18,7 \\
\hline $\begin{array}{l}\text { Auditor Dysfunctionality }(\mathrm{Y}) \rightarrow \text { Auditor } \\
\text { Professional Ability (Z) }\end{array}$ & $-0,248$ & 0,887 & 22,2 \\
\hline
\end{tabular}

Notes: Error Degree $10 \%$ or 0,1

Source: SmartPLS Software Statistical Results 3, 2020 
Based on the results Determination Analysis Coefficient in output Table 2 above, an Auditor Workload provides an estimated contribution of $18,7 \%$ to a Dysfunctional Auditor at Public Accounting Firms in Java. Then, a Dysfunctional Auditor gave an estimated contribution is $22,2 \%$ to Auditor Professional Ability at Public Accounting Firms in Java. A specific time level pressure is needed to encourage auditors to work more efficiently. However, excessive pressure related to evaluating their performance will cause stress on auditors. It will trigger them to perform dysfunctionally and impact Auditors Professional Ability (Chen et al., 2020). Donnelly et al. (2003) state that "Dysfunctional Audit Behavior is dangerous for the profession, but the profession has a good understanding of behavior, such as holding training or changes in the reward system so that the dysfunctional effects can be minimized as much as possible. In line with Yuen et al. (2013) states "Increased mental workload can result in significant audit judgment errors, and auditors can release that pressure through dysfunctional behavior."

\section{DISCUSSION AND CONCLUSION}

The workload caused by audit activities large number so that it takes the same time to complete it can lead to behavior that deviates from organizational goals, but its existence can be minimized, such as carrying out a policy Professional Judgment and Decision Behavior according to Chen et al., (2020) it means that there is a heavy workload then a auditor makes a decision to behave, where a behavior has positive and negative impacts, then still according to Chen et al., (2020) there is a heavy auditor workload and accumulated work affecting individuals to change their attitudes or behavior in an effort to align with existing rules and be professional in conducting audits, so that an Auditor Workload has a positive effect on an Dysfunctional Auditor, in fact it is in line with statement Anggraini and Nafasati (2018) which states that attitudes will influence behavior, same thing was conveyed by Pesireron (2018) which states that public accountants must understand attitudes in order to understand and predict behavior.

Public Accountants tend to reduce Auditor Professional Capability because they are under a heavy workload and audit procedures premature termination risk impact is often carried out by auditors, especially in these conditions (Al Shbail et al., 2018). The same thing was conveyed by Dahlia and Octavianty (2016). They state that Dysfunctional Auditor is individual behavior that is contrary to basic organization goals. However, Putri, Maslichah, and Mawardi (2019) state that dysfunctionality is directly related to Auditor Professional Ability. It is in line with Suhayati (2012), which states that dysfunctionality has serious implications for resulting in audit quality.

A high workload can cause fatigue if it has to be completed at the same time. Fatigue can cause tension or psychological stress related to chronic stress, which a person experiences daily is characterized by physical, mental, and emotional fatigue. It can cause premature sign-off, underreporting of time, and dysfunctional audit emergence behavior causing a decrease in auditors' professional ability and work quality performance. This is in line with research by Syarif \& Fitriyani (2017), which states that auditors who have a high workload can be dysfunctional and result in a decrease in auditor performance. The workload is a combined quantitative and qualitative work task. Quantitative workload arises from too many tasks, while qualitative workload if a worker feels unable to carry out the task or task, doesn't use worker skills or potential (Hussin et al., 2018). The workload is a set of several activities that an organizational unit must complete within a certain time period (Irzal, 2016). Demands existence of time pressure can reduce positive attitudes to behave when conducting audits. The adverse effects it causes are premature sign-off, underreporting of time, and feelings of failure when auditing so that auditors' professional ability decreases (Shbail et al., 2018).

Auditors' Dysfunctional Attitude harms Auditor Professional Ability, which means that a psychological condition that causes a person to become dysfunctional at work is an individual response due to an imbalance between workload and an ability to complete work. Therefore, an auditor's dysfunctional behavior is deviant behavior carried out by an auditor, which can directly or indirectly cause an Auditor's Professional Ability to decline. Behavior depends on attitude can be positive and can be negative. Dysfunctionality is a negative behavior, but its existence can be minimized so that auditors can increase their work effectively. 


\section{LIMITATION}

Professionalism is a quality, quality, and behavior that are professional characteristics or professional person. A profession does require professionalism because a job function has rules that must be obeyed and fulfilled. Professionalism can be seen in behavior because professional behavior reflects professionalism. Therefore, an emphasis on professionalism is more based on a person's attitude in exposing various problems related to the work he is handling. When someone with a specific profession has been wise in terms of responsibility demands according to his job, that person can be said to be a professional (Dahlia \& Octavianty, 2016). Any intervention that comes from outside can be seen as an obstacle to disrupting professional autonomy. Few people want jobs that give them the right to make decisions, privilege, and work without being closely supervised. In a structured and strictly controlled position by management, it will be challenging to create tasks that create a sense of independence in functions, so hard work is needed to improve quality. A belief that most authorized and entitled to evaluate professional work are fellow professions, not people outside an environment who do not have competence and knowledge related to their professional fields. Auditors must increase professionalism so that they are accountable for both others and themselves. Therefore, continuing professional education is absolutely necessary regarding data computerization on the latest transactions complexity in the audit sector and changes in the financial sector concerning currency measurement values.

Research on Auditor Professional Ability, only examined from an Workload and Auditor Dysfunctional variables, preferably for subsequent research using other variables such as the Time Budget variable to an Dysfunctional Auditor variable and an Auditor Dysfunctional variable to an Audit Quality with more public accounting firms in different areas wider.

\section{REFERENCES}

Al Shbail, M. O., Salleh, Z., \& Nor, M. N. M. (2018). The effect of ethical tension and time pressure on job burnout and premature signoff. Journal of Business and Retail Management Research, 12(4).

Anggraini, E. M. (2018). Pengaruh Stres Kerja Terhadap Perilaku Disfungsional Audit
Dengan The Big Five Personality Dan Locus of Control Sebagai Variabel Moderasi (Studi Pada KAP Di Wilayah Jawa Tengah Dan DIY). Solusi, 16(2).

Arens, A. A., Elder, R. J., Beasley, M. S., \& Hogan, C. E. (2016). Auditing and assurance services. Auditing and Assurance Services.

Chen, J., Dong, W., Han, H., \& Zhou, N. (2020). Does audit partner workload compression affect audit quality?. European Accounting Review, 29(5), 1021-1053.

Dahlia, L., \& Octavianty, E. (2016). Pengaruh Kompetensi, Independensi, dan Profesional Auditor Terhadap Kualitas Audit. Jurnal IImiah Akuntansi, 2(1).

Donnelly, D. P., Quirin, J. J., \& O’Bryan, D. (2003). Attitudes toward dysfunctional audit behavior: The effects of locus of control, organizational commitment, and position. Journal of Applied Business Research (JABR), 19(1).

Manalu, E. S. (2016). Pengaruh Profesionalisme, Independensi, Kompetensi, Dan Pengalaman Kerja Terhadap Kualitas Audit Di Kantor Akuntan. Journal of Accounting and Business StudieS, 1(1).

Heri, S. (2017). Auditing \& Asurans Pemeriksaan Akuntansi Berbasis Standar Audit Internasional. Gramedia Widiasarana Indonesia.

Hussin, W. N. W., Bamahros, H. M., \& Shukeri, S. N. (2018). Lead engagement partner workload, partner-client tenure and audit reporting lag: Evidence from Malaysia. Managerial Auditing Journal, 33(3), pp 246-266.

Institute Akuntan Publik Indonesia in collaboration with Kementrian Keuangan Republik Indonesia and Sekretariat Jenderal Pusat Pembinaan Akuntan and Jasa Penilai. (2020). Directory Kantor Akuntan Publik dan Akuntan Publik.

Irzal, M. K. (2016). Dasar-Dasar Kesehatan dan Keselamatan Kerja: Edisi 1. Kencana.

Jaya, S. M., Sudarma, M., \& Roekhudin, R. (2018). Role of auditor performance mediation in acceptance of auditor dysfunctional behavior: attribution theory perspective and role theory. Jurnal Aplikasi Manajemen, 16(4), 673-685. 
Liu, J. (2015). Study on the auditing theory of socialism with Chinese characteristics. John Wiley \& Sons.

Longo, L., \& Leva, M. C. (Eds.). (2019). Human Mental Workload: Models and Applications: Second International Symposium, $H$ WORKLOAD 2018, Amsterdam, The Netherlands, September 20-21, 2018, Revised Selected Papers, 1012. Springer.

Mufarrikoh, Z. (2019). Statistika Pendidikan (Konsep Sampling dan Uji Hipotesis). Jakad Media Publishing.

McNamara, S. M., \& Liyanarachchi, G. A. (2008). Time budget pressure and auditor dysfunctional behaviour within an occupational stress model. Accountancy Business and the Public Interest, 71), 1-43.

MAKs, R. P. S., \& Ak, C. A. (2019). Pemeriksaan Akuntansi: Dan Contoh Kasus di Indonesia. PT. Scopindo Media Pustaka.

Pesireron, S. (2018). Pengaruh Keterampilan, Jobb Stress Dan Disiplin Kerja Terhadap Kinerja Auditor Inspektorat (Study Empiris Pada Inspektorat Kabupaten Seram Bagian Timur dan Kabupaten Maluku Tengah). Jurnal Maneksi, 5(1), 26-31.

Edy Herry Pryhantoro, M. (2016). Korupsi dalam perspektif teori sosial kontemporer. Spasi.

Puspita, W. (2018). Manajemen Konflik: Suatu Pendekatan Psikologi, Komunikasi, dan Pendidikan. Deepublish.

Putri, D. M., Maslichah, M., \& Mawardi, M. C. (2019). Pengaruh Kompetensi Auditor Eksternal dan Disfungsional Auditor Eksternal terhadap Kualitas Audit. Jurnal IImiah Riset Akuntansi, 8(08).

Saleh, L. M. (2018). Man Behind the Scene Aviation Safety. Deepublish.

Putro, W. W., \& Sari, S. I. K. (2018). Ergonomi untuk Pemula:(Prinsip Dasar \& Aplikasinya). Universitas Brawijaya Press.

Suhayati, E. 2012. Faktor-faktor yang mempengaruhi Perilaku Disfungsional Akuntan Publik dan Implikasinya pada Kualitas Audit. Desertasi. Universitas Padjajaran.

Sunaryo, K. (2018). Sistem Pengendalian Manajemen dan Perilaku Disfungsional: Studi Empiris terhadap 12 BUMN Industri Strategis di Indonesia. CergasPublika.
Supriyono, R. A. (2018). Akuntansi Keperilakuan. UGM PRESS.

Syarif, D., \& Fitriyani, N. N. (2017). Pengaruh Etika Profesi Akuntan, Pengalaman Kerja, Tekanan Waktu, dan Beban Kerja terhadap Kualitas Audit pada 16 Kantor Akuntan Publik Di Bandung. Jurnal Indonesia Membangun, 16(1).

Unaradjan, D. D. (2019). Metode penelitian kuantitatif. Penerbit Unika Atma Jaya Jakarta.

Vanchapo, A. R., \& MKes, M. (2020). Beban kerja dan stres kerja. Penerbit Qiara Media.

Yuen, D. C., Law, P. K., Lu, C., \& Guan, J. Q. (2013). Dysfunctional auditing behaviour: empirical evidence on auditors' behaviour Macau. International Journal of Accounting \& Information Management, 21(3), 209-226.

\section{ABOUT THE AUTHORS}

Ely Suhayati, email: ely.suhayati@email.unikom.ac.id

Ely Suhayati is a lecturer of Accounting Department, Faculty of Economic and Business, Universitas Komputer Indonesia, Bandung, West Java, Indonesia 